\title{
Analisis Kelayakan Pengembangan Usaha Peternakan Sapi Perah KUNAK (Studi Kasus Usaha Ternak Kavling 176, Desa Pamijahan Kab. Bogor)
}

\author{
Nikki Ariesta Poetri \\ Departemen Manajemen, Fakultas Ekonomi dan Manajemen \\ Institut Pertanian Bogor \\ Kampus Dramaga Bogor 16680 \\ Abdul Basith \\ Departemen Manajemen, Fakultas Ekonomi dan Manajemen \\ Institut Pertanian Bogor \\ Kampus Dramaga Bogor 16680 \\ Nur Hadi Wijaya \\ Departemen Manajemen, Fakultas Ekonomi dan Manajemen \\ Institut Pertanian Bogor \\ Kampus Dramaga Bogor 16680 \\ e-mail: nur.hadi.wijaya@gmail.com
}

\begin{abstract}
Milk is one of farm commodities with high consumption level. Nevertheless, the gap between production and consumption of milk requires us to import this product from other countries. Furthermore, business development is necessary in order to fulfill the needs of national milk consumption. 'Kavling $176^{\prime}$ ' is one of the farms that supplies milk production, therefore, there is a need to conduct feasibility analysis to 'kavling 176'. Feasibility analysis is used to determine 1) non financial aspects of the business; 2) business development opportunities of the financial aspects; 3) sensitivity analysis of business. The methods used in the financial aspects are Net Present Value (NPV), Internal Rate of Return (IRR), Net B/C Ratio, Payback Period (PBP) and Break Event Point (BEP). Based on the objective, it was found that : 1) business are feasible according to the non financial aspects; 2) business development can be carried out with value NPV Rp 292514 822.00, IRR 25.93\%, Net B/C Ratio 1,42, PBP 2.83 years, and BEP Rp 225155564.00 ; 3) business are sensitive to decrease production up to $22 \%$ and combined conditions up to $63 \%$.

Keywords: feasibility analysis, financial, non financial, milk, sensitivity analysis
\end{abstract}

\begin{abstract}
ABSTRAK
Susu adalah salah satu komoditi peternakan dengan tingkat konsumsi tinggi. Namun, kesenjangan antara produksi dan konsumsi susu mengharuskan kita untuk melakukan impor dari negara lain. Selanjutnya, pembangunan usaha diperlukan untuk memenuhi kebutuhan konsumsi susu nasional. 'Kavling 176' adalah salah satu peternakan yang membantu memasok produk susu. Oleh karena itu, dibutuhkan analisis kelayakan usaha pada 'kavling 176'. Analisis kelayakan digunakan menentukan 1) aspek non finansial usaha; 2) potensi pengembangan usaha dari aspek finansial; 3) analisis sensitivitas usaha. metode yang digunakan dalam aspek finansial adalah Net Present Value (NPV), Internal rate of return (IRR), Net B/C Ratio, Payback Period (PBP) dan Break Event Point (BEP). Berdasarkan tujuan, hasil yang diperoleh adalah 1) usaha dinyatakan layak menurut aspek non finansial; 2) pengembangan bisnis dapat dilakukan dengan nilai NPV Rp 292514 822.00, IRR 25.93\%, Net B/C Ratio 1.42, PBP 2.83 tahun,
\end{abstract}


dan BEP Rp 225155 564.00; 3) usaha dinyatakan sensitif pada penurunan produksi hingga 17\% dan kondisi gabungan hingga $7 \%$.

Kata kunci: analisis kelayakan, analisis sensitivitas, finansial, non finansial, susu

\section{Pendahuluan}

Susu merupakan salah satu komoditi hasil peternakan dengan tingkat konsumsi mencapai 11.09 liter per kapita pada tahun 2011 dan meningkat menjadi 14.6 liter per kapita pada tahun 2012. Tingkat konsumsi ini terus meningkat seiring dengan pertumbuhan jumlah penduduk, namun kenaikan tingkat konsumsi susu tidak diimbangi dengan kontribusi produksi susu domestik. Tahun 2012, produk susu domestik hanya mampu memenuhi 30\% kebutuhan nasional, sedangkan sisanya dipenuhi melalui susu impor (Ditjen PKH 2012). Data pada Tabel 1 menunjukan perbandingan antara tingkat konsumsi dengan produksi susu nasional pada tahun 2008-2012.

Tabel 1. Perbandingan tingkat konsumsi dan produksi susu nasional (000 ton)

\begin{tabular}{lccccc}
\hline \multirow{1}{*}{ Tingkat- } & \multicolumn{5}{c}{ Tahun } \\
\cline { 2 - 6 } & $\mathbf{2 0 0 8}$ & $\mathbf{2 0 0 9}$ & $\mathbf{2 0 1 0}$ & $\mathbf{2 0 1 1}$ & $\mathbf{2 0 1 2}$ \\
\hline Konsumsi & 2125.3 & 2277.2 & 2506.4 & 2672.69 & 3573.64 \\
Produksi & 647.0 & 827.2 & 909.5 & 974.7 & 1017.9 \\
Gap & $(1478.3)$ & $(1450.0)$ & $(1596.9)$ & $(1697.99)$ & $(2555.74)$ \\
\hline
\end{tabular}

Sumber : Ditjen PKH 2012 (data diolah, 2013)

Kontribusi susu domestik dalam memenuhi kebutuhan susu nasional mayoritas berasal dari Pulau Jawa. Namun dengan jumlah penduduk yang tinggi, Pulau Jawa juga menjadi daerah dengan tingkat konsumsi susu tertinggi. Hal ini mengakibatkan terjadinya kesenjangan antara konsumsi dan produksi susu di setiap provinsi di Pulau Jawa. Data dari Departemen Pertanian menunjukan kesenjangan yang terjadi dalam kurun waktu tiga tahun. Data pada Tabel 2 menunjukan gap antara produksi dan konsumsi di Pulau Jawa.

Tabel 2. Perbandingan nilai produksi dan konsumsi susu di Pulau Jawa (ton)

\begin{tabular}{lcccccc}
\hline \multirow{2}{*}{ Provinsi } & \multicolumn{5}{c}{$\mathbf{2 0 0 8}$} & \multicolumn{3}{c}{$\mathbf{2 0 0 9}$} \\
\cline { 2 - 7 } & Produksi & Konsumsi & Gap & Produksi & Konsumsi & Gap \\
\hline D.K.I Jakarta & 6.388 & 252.714 & $(246.326)$ & 5.723 & 294.706 & $(288.983)$ \\
Jawa Barat & 225.212 & 355.850 & $(130.638)$ & 255.348 & 488.947 & $(233.599)$ \\
Jawa Tengah & 89.748 & 230.588 & $(140.840)$ & 91.762 & 388.012 & $(296.250)$ \\
D.I Yogyakarta & 7.083 & 26.946 & $(19.863)$ & 5.038 & 58.700 & $(53.662)$ \\
Jawa Timur & 312.270 & 401.929 & $(89.659)$ & 461.880 & 502.780 & $(40.900)$ \\
Banten & 0 & 86.509 & $(86.509)$ & 0 & 212.739 & $(212.739)$ \\
\hline
\end{tabular}

Sumber : Ditjen PKH 2012 Hewan (data diolah, 2013)

Berdasarkan Tabel 2, nilai kesenjangan yang terjadi antara produksi dan konsumsi susu mengalami kenaikan tiap tahunnya. Di Provinsi Jawa Barat, gap yang terjadi selama 2 tahun terakhir, mengalami peningkatan yang signifikan. Hal ini menandakan belum terpenuhinya kebutuhan masyarakat dalam mengkonsumsi susu. 
Konsekuensi akibat tingginya kesenjangan produksi dan konsumsi susu adalah ketergantungan terhadap impor dalam memenuhi permintaan susu dalam negeri. Hal yang dapat dilakukan untuk mengurangi ketergantungan impor, yaitu dengan menggiatkan produksi susu nasional melalui usaha sapi perah (Siregar 2004). Sudono dalam Adi et al. (2005) menjelaskan beberapa keuntungan beternak sapi perah dibandingkan usaha ternak lainnya, yaitu : 1) usaha ternak sapi perah merupakan suatu usaha yang tetap; 2) jaminan pendapatan yang tetap; 3) penggunaan tenaga kerja yang tetap; 4) dapat menggunakan berbagai macam hijauan yang tersedia atau sisa hasil pertanian; 5) kesuburan tanah dapat dipertahankan. Menurut Yusdja (2005) struktur produksi sapi perah terdiri dari usaha skala besar (UB) dengan kepemilikan sapi lebih dari 100 ekor, usaha menengah (UM) dengan kepemilikan sapi sebanyak 30100 ekor, usaha kecil (UK) dengan kepemilikan sapi sebanyak 10-30 ekor dan usaha rakyat (UR) dengan kepemilikan sapi sebanyak 1-9 ekor.

Nurtini (2011) menyatakan bahwa usaha peternakan sapi perah Indonesia dibedakan menjadi dua jenis : 1) Usaha peternakan sapi perah rakyat; 2) Perusahaan peternakan sapi perah. Sebagian besar, susu yang diproduksi dalam negeri berasal dari usaha peternakan sapi perah rakyat. Kontribusi usaha sapi perah rakyat bagi produksi susu nasional adalah sebesar $90 \%$. Jawa Barat sebagai provinsi yang menempati urutan kedua dalam produksi dan konsumsi susu memiliki potensi pengembangan usaha susu sapi yang cukup baik. Salah satu wilayah di Jawa Barat yang memiliki potensi dalam pengembangan usaha susu sapi adalah Kabupaten Bogor. Tabel 3 menunjukan perkembangan produksi susu di Kabupaten Bogor dalam kurun waktu tujuh tahun.

Tabel 3. Perkembangan produksi susu sapi perah di Kabupaten Bogor (kg)

\begin{tabular}{lcccccccc}
\hline \multirow{2}{*}{ Wilayah } & \multicolumn{7}{c}{ Tahun } \\
\cline { 2 - 9 } & $\mathbf{2 0 0 4}$ & $\mathbf{2 0 0 5}$ & $\mathbf{2 0 0 6}$ & $\mathbf{2 0 0 7}$ & $\mathbf{2 0 0 8}$ & $\mathbf{2 0 0 9}$ & $\mathbf{2 0 1 0}$ & $\mathbf{2 0 1 1}$ \\
\hline Kotamadya & 3508 & 2263 & 1432 & 1782 & 1965 & 2059 & 2072 & 1813 \\
Kabupaten & 11656 & 11828 & 11149 & 11464 & 12855 & 15518 & 15860 & 19499 \\
Jumlah & 15164 & 14091 & 12581 & 13246 & 14820 & 17577 & 17932 & 21312 \\
\hline
\end{tabular}

Sumber : Ditjen PKH 2012 (data diolah, 2013)

Peningkatan produksi di Kabupaten Bogor mengalami kenaikan yang signifikan dari tahun 2007-2011. Hal ini disebabkan oleh ketersediaan lahan yang cukup dibandingkan dengan Kotamadya Bogor. Salah satu daerah di Kabupaten Bogor yang merupakan kawasan peternakan adalah KUNAK. KUNAK memiliki lahan total dengan luas 121.06 hektar dengan total kavling sebanyak 181 . Setiap kavling memiliki luas tanah rata-rata $5000 \mathrm{~m}^{2}$ yang terdiri dari rumah tipe $21 \mathrm{~m}^{2}$, kandang dengan kapasitas 12 ekor dan lahan untuk menanam rumput. KUNAK terbagi menjadi tiga lokasi, yaitu KUNAK I, KUNAK II dan KUNAK III. Daerah KUNAK III yang berupa lereng terjal dan curam menyebabkan daerah ini sulit diakses dan terbengkalai. Daerah KUNAK I, terletak di Desa Situ Udik dan sebagian lagi terletak di Desa Pasarean. Sementara itu, KUNAK II, terletak di Desa Pamijahan, Kecamatan Pamijahan. Daerah ini memiliki ketinggian 350-415 $\mathrm{m}$ dpl dengan suhu rata-rata $15-31^{\circ} \mathrm{C}$. Kelompok peternak yang terdapat di KUNAK II, yaitu kelompok indah, kelompok aman dan kelompok mandiri. Salah satu peternak yang masih bertahan di kelompok mandiri adalah usaha ternak kavling 176. Usaha ini telah berdiri sejak awal peresmian daerah KUNAK. Peran studi 
kelayakan usaha menjadi faktor penting sebagai rekomendasi kepada pemilik usaha untuk menjaga keberlangsungan usaha. Studi kelayakan usaha menentukan kelayakan suatu usaha untuk dijalankan atau dikembangkan. Studi tersebut akan memberikan gambaran tentang manfaat, keuntungan, dan prospek usaha yang diperoleh. Pemaparan di atas menjadi dasar dilakukannya penelitian tentang studi kelayakan usaha ternak sapi perah kavling 176.

Perumusan masalah pada penelitian ini : 1) Bagaimana kondisi saat ini dari usaha peternakan kavling 176 di Desa Pamijahan, Kabupaten Bogor dilihat dari aspek non finansial?; 2) Bagaimana pengembangan usaha yang mungkin dilakukan peternakan kavling 176 di Desa Pamijahan, Kabupaten Bogor dilihat dari aspek finansial?; 3) Bagaimana analisis sensitivitas usaha peternakan sapi perah terhadap kemungkinan terjadinya kenaikan harga input dan penurunan harga output?

Tujuan penelitian ini : 1) Menganalisis kondisi saat ini dari usaha peternakan kavling 176 di Desa Pamijahan, Kabupaten Bogor dilihat dari aspek non finansial; 2) Menganalisis pengembangan usaha yang mungkin dilakukan peternakan kavling 176 di Desa Pamijahan, Kabupaten Bogor dilihat dari aspek finansial; 3) Menganalisis sensitivitas usaha peternakan sapi perah terhadap kemungkinan terjadinya kenaikan harga input dan penurunan harga output.

\section{Metode Penelitian}

Penelitian ini dilakukan di Kawasan Usaha Peternakan (KUNAK) sapi perah yang terletak di Kabupaten Bogor. Pengumpulan data penelitian dilaksanakan pada bulan Mei hingga Juli 2013. KUNAK II terletak di Kabupaten Bogor, tepatnya di Desa Pamijahan Kecamatan Pamijahan. Daerah KUNAK II memiliki prospek pengembangan usaha apabila dilihat dari lokasinya yang berada di dataran tinggi dengan suhu udara sejuk dan ketersediaan air langsung dari sumber mata air pegunungan.

Usaha ternak kavling 176 yang merupakan bagian dari daerah KUNAK II memiliki peluang pengembangan usaha. Usaha ini dikatakan memiliki peluang pengembangan karena usaha ini merupakan salah satu peternakan yang masih bertahan di KUNAK sejak pertama kali lokasi ini didirikan tahun 1997.

Analisis dilakukan dengan mempertimbangkan aspek non finansial seperti aspek pasar, teknis, manajemen, hukum, sosial, ekonomi dan lingkungan. Sedangkan analisis kelayakan usaha dilihat dari aspek finansial akan dikaji melalui beberapa kriteria investasi. Adapun kriteria investasi yang digunakan, yaitu Net Present Value (NPV), rasio manfaat biaya (Net B/C), Internal Rate of Return (IRR), dan Payback Period (PP) (Nurmalina et al 2009). Rumus nilai bersih kini, sebagai berikut :

$$
\mathrm{NPV}={ }_{t=1}^{n} \frac{B t}{(1+i)^{t}}-{ }_{t=1}^{n} \frac{C t}{(1+i)^{t}}={ }_{t=1}^{n} \frac{B t-C t}{(1+i)^{t}} \quad \ldots \ldots
$$

Keterangan :

Bt : manfaat pada tahun $\mathrm{t}$

$\mathrm{Ct}$ : biaya pada tahun $\mathrm{t}$

$\mathrm{t}$ : tahun kegiatan usaha $(\mathrm{t}=1,2,3 \ldots, \mathrm{n})$, tahun awal bias tahun 1 bergantung pada karakteristik usahanya

i : tingkat discount factor pada tahun ke-t 


$$
\operatorname{Net} \frac{B}{C}=\frac{\substack{t=1 \\ t=1} \frac{B t-C t}{(1+i) t}_{t=1}^{n} \frac{B t-C t}{(1+i)^{t}}}{\ldots \ldots \ldots}
$$

Keterangan :

Bt : manfaat pada tahun $\mathrm{t}$

Ct : biaya pada tahun $\mathrm{t}$

$\mathrm{t}$ : tahun kegiatan usaha $(\mathrm{t}=1,2,3 \ldots, \mathrm{n})$, tahun awal bias tahun 1 bergantung pada karakteristik usahanya.

i : tingkat discount factor pada tahun ke-t

$$
\mathrm{IRR}=\mathrm{i}_{1}+\frac{N P V_{1}}{N P V_{1-N P V_{2}}} \times\left(i_{2}-i_{1}\right) \ldots \ldots
$$

Keterangan :

$\mathrm{i}_{1} \quad$ : discount rate yang menghasilkan NPV positif

$\mathrm{i}_{2} \quad$ : discount rate yang menghasilakn NPV negatif

$\mathrm{NPV}_{1} \quad$ : NPV yang bernilai positif

$\mathrm{NPV}_{2} \quad$ : NPV yang bernilai negatif

$$
\text { Payback Period }=\frac{I}{A b}
$$

Keterangan :

I : besarnya biaya investasi yang diperlukan

Ab : manfaat bersih yang diperoleh pada setiap tahunnya.

Hasil analisis menunjukan apakah usaha sapi perah memberikan manfaat dari segi non finansial maupun finansial. Adapun alur kerangka pemikiran penelitian dijelaskan pada Gambar 1 di bawah ini.

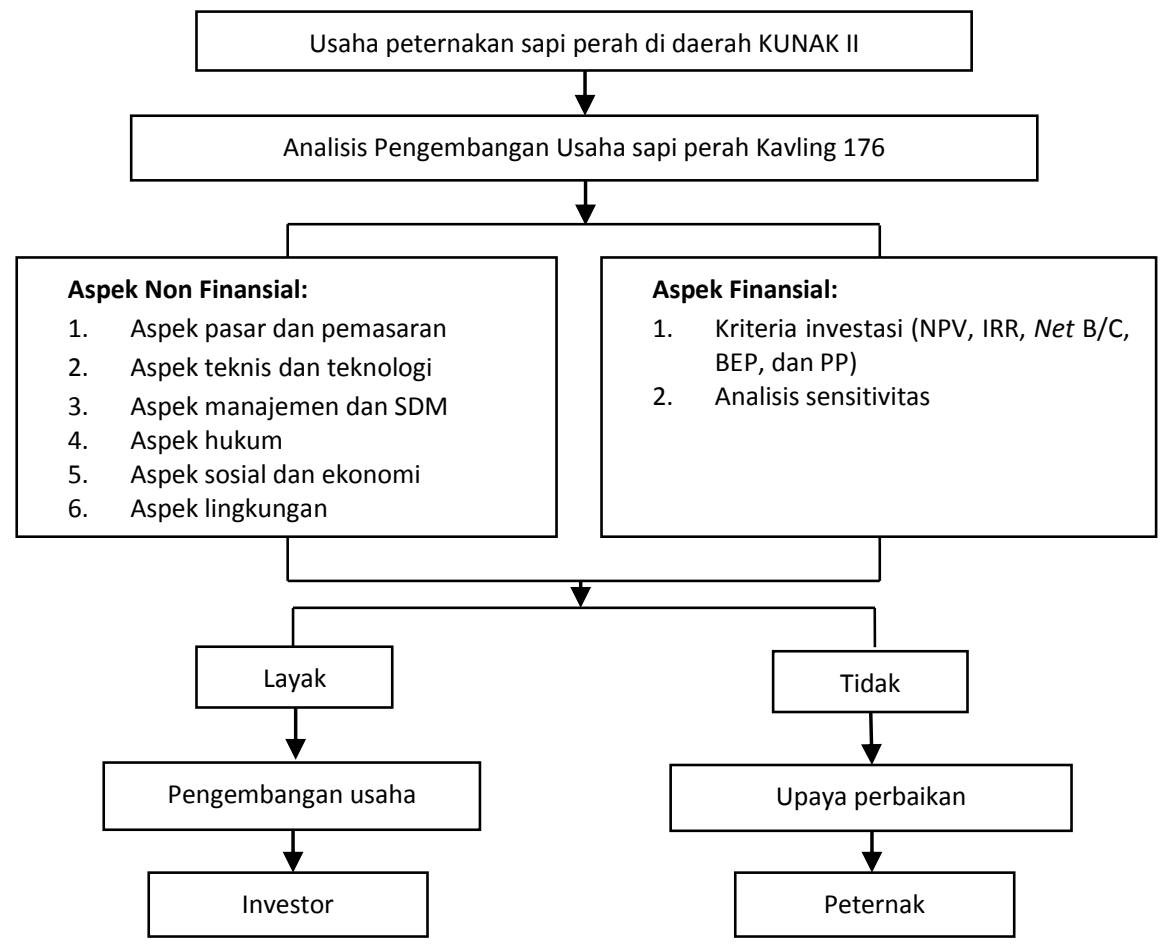

Gambar 1. Kerangka pemikiran penelitian 


\section{Hasil dan Pembahasan}

III.1. Gambaran Usaha Sapi Perah Ternak Kavling 176 di daerah KUNAK

Usaha sapi perah kavling 176 terletak di daerah KUNAK II, tepatnya di kelompok ternak mandiri. Usaha ternak ini merupakan usaha ternak dengan skala besar. Usaha ini berdiri sejak 1997 hingga sekarang dan telah memiliki sapi perah sebanyak 54 ekor. Usaha ini terdiri dari kavling dengan luas tanah $4250 \mathrm{~m}^{2}$ yang didalamnya terdapat kandang berukuran $12 \times 9 \mathrm{~m}$, lahan rumput dan rumah tipe 21 . Jenis sapi perah yang dipelihara yaitu jenis Fries Holland (FH). Selama usaha berdiri, kandang telah diperluas sebesar $360 \mathrm{~m}^{2}$. Selain itu, pada tahun 2008 dibangun juga sebuah gudang sebagai tempat penyimpanan pakan ternak.

\section{III.2. Kegiatan Produksi Susu Sapi Perah}

Hal yang harus diperhatikan saat proses pemerahan adalah kualitas susu yang tetap terjaga. Selain itu, berbagai persiapan juga dilakukan sebelum kegiatan pemerahan dilakukan. Adapun tahapan produksi susu sapi perah yang dilakukan pada usaha ternak kavling 176 adalah membersihkan kandang, mencuci daerah lipatan paha, memberi konsentrat, membersihkan alat pemerah, membersihkan tangan pemerah, mencuci ambing, memberikan krim pada ambing, proses pemerahan, membersihkan putting sapi, penyaringan susu, pengiriman susu ke KPS, proses pendinginan dan proses pemanasan.

\section{III.3. Aspek Non Finansial}

\section{Aspek Hukum}

Undang-undang yang mengatur pembiayaan pendirian KUNAK menjadi aspek hukum yang terkait dengan usaha di kavling 176, yaitu Kepres Nomor 064/B/1994 Tgl. 8 November 1994 dan Kepres Nomor 069/B/1994 Tgl. 21 Desember 1994 berisi pinjaman dana BANPRES. Bantuan tersebut didapat sebagai bentuk usaha pembangunan tata ruang dan percontohan peternakan sapi perah rakyat. Selain itu, terdapat pula status badan hukum koperasi susu nomor 4654/BH/I176-9 1970.

\section{Aspek Pasar dan Pemasaran}

Pemasaran yang dilakukan terbatas di KPS Bogor dan daerah sekitar. Pemasaran yang dilakukan usaha ternak kavling 176 dimulai dari pengumpulan produksi susu ke koperasi. Susu yang sudah disetor ke KPS akan melalui tahap pengujian untuk menentukan kualitas susu di kavling 176. Fungsi koperasi disini yaitu sebagai wadah yang mengumpulkan hasil produksi susu untuk dijual ke industri pengolahan susu (IPS). Beberapa industri yang bekerja sama dengan KPS Bogor, yaitu Cimory, Frisian Flag, dan Unican. Pada akhirnya berbagai produk olahan susu disalurkan ke masyarakat.

\section{Aspek Teknis dan Produksi}

a. Lokasi Usaha

Usaha peternakan kavling 176 terletak di KUNAK yang secara geografis termasuk ke dalam dataran tinggi dengan ketinggian 350-415 mdpl. Penentuan lokasi usaha juga dipengaruhi oleh Peraturan Daerah (Perda) Kabupaten Bogor No. 19 tahun 2008. Peraturan tersebut membahas tentang tata ruang wilayah. 
b. Layout Produksi

Kandang yang dimiliki oleh usaha ternak kavling 176 terdiri dari satu kandang asli yang telah diperbesar dan 2 kandang baru yang dibangun oleh pemilik. Posisi sapi di kandang saling membelakangi sehingga limbah dapat langsung dialirkan melaluin saluran yang berada di tengah-tengah kandang.

c. Fasilitas dan Teknologi Produksi

Pada usaha ternak kavling 176 terdapat fasilitas-fasilitas produksi yang mendukung berjalannya usaha. Kavling 176 memiliki fasilitas berupa kandang dengan ukuran 12x9 m. Selain itu, kandang di kavling 176 memiliki kemiringan sebesar $5^{\circ}$, sehingga limbah berupa kotoran sapi dapat dialirkan dan tidak menggenang. Teknologi yang digunakan pada usaha ternak kavling 176 tergolong sederhana. Proses pemerahan dilakukan secara manual yaitu dengan menggunakan tenaga manusia.

d. Bahan Pakan Ternak

Bahan pakan yang digunakan pada usaha ternak ini terdiri dari berbagai jenis, yaitu hijauan, konsentrat, ampas tahu, dan jerami. Hijauan yang digunakan adalah jenis rumput gajah. Konsentrat yang digunakan diperoleh dari koperasi susu terdekat, sedangkan ampas tahu dan jerami digunakan sebagai pakan tambahan.

e. Proses Produksi

Proses produksi susu bermula dari ketersediaan sapi dara siap kawin. Sapi dara yang telah siap kawin akan diberikan inseminasi buatan (IB) oleh petugas medis KPS. Sapi yang telah melahirkan baru dapat diperah pada hari keempat. Pada bulan pertama produksi masih rendah, kemudian meningkat hingga mencapai puncaknya pada bulan ketiga. Susu yang telah diperah akan disetor ke KPS.

f. Jumlah dan Mutu Produksi

Jumlah produksi per hari yang dihasilkan oleh 19 ekor sapi lakstasi pada usaha kavling 176 sebesar \pm 200 liter. Mutu susu segar di kavling ini selalu dijaga dengan dilakukannya penyaringan menggunakan kain. Mutu susu juga dijaga oleh pihak KPS. Hal ini ditandai dengan adanya pengujian kualitas susu melalui uji fisik, uji alkohol 70\%, uji berat jenis, uji kadar lemak, dan uji bakteri.

g. Kendala Produksi

Kendala produksi yang dialami oleh kavling 176 adalah harga susu. Harga susu yang berkisar antara $\mathrm{Rp} 3$ 300-Rp 3400 dinilai terlalu rendah oleh pemilik usaha. Kendala lain yang dirasakan oleh kavling 176 adalah kualitas pakan ternak yang rendah. Selain itu, sikap tenaga kerja juga menjadi kendala dalam pengembangan usaha sapi perah kavling 176.

\section{Aspek Manajemen, Organisasi dan Sumber Daya Manusia (SDM)}

Sistem manajemen yang diterapkan dalam usaha ternak kavling 176 masih sederhana. Hal tersebut dikarenakan belum ada pembagian khusus untuk bagianbagian seperti keuangan, produksi, maupun pemasaran secara terpisah. Pemilik usaha bertindak sebagai pengelola secara langsung dan menangani bagian keuangan, tenaga produksi dan pemasaran. Selain pemilik, pihak yang terlibat dalam usaha ternak sapi 
perah adalah petugas kandang. Secara umum, satu orang petugas kandang mampu mengurus 10-12 ekor sapi perah. Pada kasus kavling 176 tenaga kerja yang digunakan yaitu sebanyak 3 orang dengan gaji sebesar Rp 1000000 per orang tiap bulan.

\section{Aspek Sosial Ekonomi}

Keberadaan usaha ternak kavling 176 membantu mengurangi pengangguran dengan cara memberikan lapangan kerja kepada warga sekitar. Munculnya pekerjaan lain seperti penjual jerami ataupun jasa pengaritan rumput merupakan dampak lain dari keberadaan usaha ternak sapi perah. Selain itu, infrastrukstur yang ada akibat pembangunan daerah KUNAK seperti jalan aspal, jembatan, drainase, supply air, listrik dan mushola juga menambah kesejahteraan warga sekitar.

\section{Aspek Lingkungan}

Limbah dari usaha ternak akan memberikan dampak kepada lingkungan. Oleh karena itu dibutuhkan sistem pengelolaan yang tepat agar limbah tersebut tidak mencemari lingkungan. Limbah kotoran ternak yang dihasilkan oleh setiap ekor sapi perah adalah sebanyak $20 \mathrm{~kg}$ per hari. Namun, pada usaha ternak ini kotoran sapi masih terbatas pengelolaanya, yaitu dengan mengalirkan kotoran ke ladang rumput melalui saluran kecil sehingga berpotensi menimbulkan pencemaran lingkungan berupa bau tidak sedap dan pencemaran air tanah.

\section{III.4. Aspek Finansial}

\section{Asumsi Analisis Keuangan}

Penggunaan asumsi dibutuhkan dalam analisis keuangan. Asumsi tersebut diperoleh melalui kajian terhadap usaha ternak kavling 176 dan informasi dari studi pustaka.

a. Kondisi saat ini

Adapun asumsi yang digunakan pada pengembangan usaha ternak kondisi saat ini adalah :

1) Periode analisis adalah 5 tahun, hari kerja per bulan adalah 30 hari, bulan kerja per tahun adalah 12 bulan dan masa laktasi adalah 10 bulan.

2) Usaha ini berdiri tahun 1997, tahun analisis dimulai pada tahun 2013-2018.

3) Sapi yang berada dalam masa laktasi sebanyak 19 ekor.

4) THR diperhitungkanpada biaya variabel sebesar satu kali gaji

5) Harga seluruh input diasumsikan tetap.

6) Produksi susu mengalami kenaikan di tahun kedua menjadi 265 liter/hari akibat berfungsinya sapi dara menjadi sapi laktasi sebanyak 7 ekor.

7) Penjualan sapi afkir dan dewasa dilakukan hingga tahun ketiga. Hal ini disesuaikan dengan jumlah sapi terkini yang dimiliki usaha.

8) Penyusutan menggunakan metode garis lurus.

9) Usaha berada dalam kondisi bebas dari beban (kredit, hutang, gadai).

10) Pajak yang digunakan adalah PPh berdasarkan Undang-Undang Nomor 36 Tahun 2008 yang berlaku untuk tahun 2010 dan seterusnya yaitu sebesar $12.5 \%$. 
Investasi usaha yang telah dimiliki usaha ternak kavling 176 dari awal mendirikan usaha hingga kini mencapai Rp 879833 000. Investasi yang dimiliki sekarang, diperoleh secara bertahap selama 16 tahun. Tabel 4 di bawah ini, menunjukan rincian biaya investasi usaha sapi perah kavling 176.

Tabel 4. Rincian biaya investasi kondisi saat ini

\begin{tabular}{lcccl}
\hline Komponen Biaya & Satuan & Jumlah Fisik & $\begin{array}{c}\text { Harga } \\
\text { (Rp) }\end{array}$ & $\begin{array}{c}\text { Jumlah } \\
\text { Biaya (Rp) }\end{array}$ \\
\hline Ternak & Ekor & 54 & 10000000 & 540000000 \\
Tanah & $\mathrm{m}^{2}$ & 4250 & 12316 & 52343000 \\
Bangunan kandang & $\mathrm{m}^{2}$ & 360 & 500000 & 180000000 \\
Bangunan gudang & $\mathrm{m}^{2}$ & 9 & 500000 & 4500000 \\
Mobil pick up & Unit & 1 & 60000000 & 60000000 \\
Motor & Unit & 3 & 7000000 & 21000000 \\
Peralatan & Unit & & & 21990000 \\
\hline \multicolumn{1}{c}{ Total } & & & $\mathbf{8 7 9 8 3 3 0 0 0}$ \\
\hline
\end{tabular}

Bangunan kandang yang diperhitungkan adalah kandang yang dibangun sendiri di luar kandang yang sudah disediakan pada setiap kavling. Hal ini menunjukan bahwa total kandang yang dimiliki seluas $468 \mathrm{~m}^{2}$.

Biaya operasional yang dibutuhkan dalam usaha ini terbagi menjadi biaya variabel dan biaya tetap. Tabel 5 menunjukan rincian biaya variabel yang dibutuhkan dalam pengelolaan usaha sapi perah.

Tabel 5. Rincian biaya variabel kondisi saat ini

\begin{tabular}{|c|c|c|c|c|}
\hline Komponen Biaya & Satuan & Jumlah & $\begin{array}{c}\text { Biaya per Satuan } \\
\text { (Rp) }\end{array}$ & $\begin{array}{c}\text { Jumlah Biaya per } \\
\text { Tahun (Rp) }\end{array}$ \\
\hline \multicolumn{5}{|l|}{ Pakan } \\
\hline Konsentrat & Karung & 45.00 & 80000 & 43200000 \\
\hline Ampas tahu & Karung & 30.00 & 14000 & 5040000 \\
\hline Jerami & Ikat & 960.00 & 2500 & 28800000 \\
\hline \multicolumn{5}{|l|}{ Overhead Lainnya } \\
\hline Vaseline & $\mathrm{Kg}$ & 3.00 & 32000 & 1152000 \\
\hline Ember & Unit & 1.30 & 8000 & 124800 \\
\hline Sepatu boot & Pasang & 3 & 80000 & 240000 \\
\hline Saringan kain & Unit & 0.67 & 5000 & 40200 \\
\hline Sikat & Unit & 0.34 & 5000 & 20400 \\
\hline \multicolumn{5}{|l|}{ Biaya medis } \\
\hline Obat-obatan & Bulan & 1.00 & 125000 & 1500000 \\
\hline Vitamin & Botol & 3.00 & 18000 & 648000 \\
\hline \multicolumn{5}{|l|}{ Transportasi } \\
\hline $\begin{array}{l}\text { Mobil dan motor } \\
\text { Gaji }\end{array}$ & Liter/bulan & 222.00 & 4500 & 11988000 \\
\hline Karyawan \& THR & Bulan & 3 & 1000000 & 39000000 \\
\hline Total Biaya Variabel & & & & 131753400 \\
\hline
\end{tabular}

Biaya variabel terdiri dari biaya pakan ternak, biaya overhead, biaya medis dan transportasi dan biaya gaji. Biaya variabel yang dibutuhkan dalam setahun untuk mengelola 54 ekor sapi, yaitu sebesar Rp 131753400.

Biaya tetap pada usaha sapi perah kavling 176 terdiri secara rincian ditunjukan oleh Tabel 6. 
Tabel 6. Rincian biaya tetap kondisi saat ini

\begin{tabular}{lcccl}
\hline Komponen Biaya & Satuan & Jumlah & Biaya per Unit (Rp) & Total Biaya (Rp) \\
\hline Listrik & Bulan & 1 & 200000 & 2400000 \\
Air & Bulan & 1 & 140000 & 1680000 \\
Pajak PBB & Tahun & 1 & 250000 & 250000 \\
Pajak mobil & Unit/tahun & 1 & 1300000 & 1300000 \\
Pajak motor & Unit/tahun & 3 & 250000 & 750000 \\
Pajak desa & Tahun & 1 & 250000 & 250000 \\
Cicilan kavling & Bulan & 1 & 273000 & 3276000 \\
Gaji pemilik & Orang/tahun & 1 & 2500000 & 32500000 \\
\hline Total Biaya Tetap & & & $\mathbf{4 2 4 0 6 0 0 0}$ \\
\hline
\end{tabular}

Biaya tetap usaha ternak kavling 176 terdiri dari : biaya listrik, air, pajak dan cicilan kavling. Biaya tetap yang dibutuhkan selama setahun, yaitu sebesar Rp 42906000.

Pendapatan usaha ternak kavling 176 berasal dari penjualan susu ke KPS dan ke sekolah terdekat. Selain dari penjualan susu, pendapatan lainnya bersal dari penjualan sapi afkir dan sapi dewasa. Sapi dewasa yang dijual biasanya berumur 22 bulan dengan harga Rp 10000 000. Tabel 7 menunjukan rincian pendapatan yang diperoleh usaha setiap tahunnya.

Tabel 7. Penerimaan usaha ternak kondisi saat ini

\begin{tabular}{lccccc}
\hline \multicolumn{1}{c}{ Uraian } & Tahun 1 & Tahun 2 & Tahun 3 & Tahun 4 & Tahun 5 \\
\hline $\begin{array}{l}\text { Total penjualan } \\
\text { susu (Rp) }\end{array}$ & 211500000 & 272700000 & 272700000 & 272700000 & 272700000 \\
$\begin{array}{l}\text { Sapi afkir \& } \\
\text { dewasa (Rp) }\end{array}$ & 90000000 & 90000000 & 90000000 & 0 & 0 \\
\hline Total penerimaan & $\mathbf{3 0 1 5 0 0 0 0 0}$ & $\mathbf{3 6 2 7 0 0 0 0 0}$ & $\mathbf{3 6 2 7 0 0 0 0 0}$ & $\mathbf{2 7 2 7 0 0 0 0 0}$ & $\mathbf{2 7 2 7 0 0 0 0 0}$ \\
\hline
\end{tabular}

Pada tahun pertama sapi yang berproduksi sebanyak 19 ekor dengan volume produksi 205 liter/hari. Sedangkan pada tahun kedua, diasumsikan sapi dara yang dimiliki usaha kavling 176 telah menjadi sapi laktasi dengan volume produksi 265 liter/hari.

b. Kondisi Pengembangan

Adapun asumsi yang digunakan pada pengembangan usaha ternak kondisi pengembangan adalah :

1) Periode analisis adalah 5 tahun, hari kerja per bulan adalah 30 hari, bulan kerja per tahun adalah 12 bulan dan masa laktasi adalah 10 bulan.

2) Usaha ini berdiri tahun 1997, tahun analisis dimulai pada tahun 2013-2018.

3) Terjadi penambahan jumlah ternak sebanyak 40 ekor sapi laktasi dan penambahan jumlah tenaga kerja sebanyak 4 orang.

4) Harga sapi per ekor, yaitu Rp 12000000

5) Gaji tenaga kerja mengalami kenaikan sebesar 15\% dan terdapat THR di akhir tahun sebesar satu kali gaji.

6) Gaji pemiliki diasumsikan sebesar Rp 2500000 per bulan 
7) Pada bulan pertama, sapi berada dalam masa adaptasi (belum berproduksi), selanjutnya sapi berproduksi sebanyak 10 liter/ekor/hari.

8) Harga susu (output) mengalami kenaikan mulai tahun pertama sebesar $15 \%$.

9) Harga input (biaya variabel) mengalami kenaikan sebesar $15 \%$ akibat dari kenaikan harga BBM, sedangkan harga BBM yang digunakan yaitu sebesar Rp 6500.

10) Penyusutan menggunakan metode garis lurus.

11) Sumber modal yang digunakan adalah modal yang bersumber dari kredit sebesar $70 \%$ dan modal sendiri sebesar 30\%. Jangka waktu kredit untuk investasi adalah 5 tahun dan untuk modal kerja adalah 1 tahun.

12) Suku bunga yang digunakan adalah suku bunga dasar kredit BNI tanggal 30 Juni 2013, yaitu sebesar $11.6 \%$ per tahun dengan bunga flat.

13) Pajak yang digunakan adalah PPh berdasarkan Undang-Undang Nomor 36 Tahun 2008 yang berlaku untuk tahun 2010 dan seterusnya yaitu sebesar $12.5 \%$.

Biaya investasi yang dibutuhkan untuk pengembangan usaha antara lain : pembelian ternak, pembuatan kandang, dan pembelian peralatan. Tabel 8 di bawah ini, menunjukan rincian biaya investasi yang dilakukan untuk pengembangan usaha.

Tabel 8. Rincian biaya investasi kondisi pengembangan

\begin{tabular}{lcccc}
\hline $\begin{array}{l}\text { Komponen } \\
\text { Biaya }\end{array}$ & Satuan & Jumlah Fisik & $\begin{array}{c}\text { Harga } \\
\text { Perolehan (Rp) }\end{array}$ & Jumlah Biaya (Rp) \\
\hline Ternak & ekor & 40 & 12000000 & 480000000 \\
Kandang & $\mathrm{m}^{2}$ & 400 & 500000 & 200000000 \\
Peralatan & & & & 20000000 \\
\hline Total & & & & $\mathbf{7 0 0 0 0 0 0 0 0}$ \\
\hline
\end{tabular}

Biaya investasi yang dibutuhkan yaitu sebesar Rp 700000 000. Biaya ini terdiri dari pembelian 40 ekor sapi laktasi yang siap produksi dan pelebaran kandang untuk investasi ternak baru yang dilakukan.

Tabel 9. Rincian biaya variabel kondisi pengembangan

\begin{tabular}{|c|c|c|c|c|}
\hline Komponen biaya & Satuan & $\begin{array}{l}\text { Jumlah } \\
\text { Fisik }\end{array}$ & $\begin{array}{c}\text { Biaya per Satuan } \\
\text { (Rp) }\end{array}$ & $\begin{array}{c}\text { Jumlah biaya per } \\
\text { Tahun (Rp) }\end{array}$ \\
\hline \multicolumn{5}{|l|}{ Pakan } \\
\hline Konsentrat & Karung & 33 & 92000 & 36800000 \\
\hline Ampas tahu & Karung & 22 & 16100 & 4293333 \\
\hline Jerami & Ikat & 711 & 2875 & 24533333 \\
\hline \multicolumn{5}{|l|}{ Overhead Lainnya } \\
\hline Vaseline & $\mathrm{Kg}$ & 2.22 & 36800 & 981333 \\
\hline Ember & Unit & 0.96 & 9200 & 106311 \\
\hline Sepatu boot & Pasang & 4 & 80000 & 320000 \\
\hline Saringan kain & Unit & 0.50 & 5750 & 34244 \\
\hline Sikat & Unit & 0.25 & 5750 & 17378 \\
\hline \multicolumn{5}{|l|}{ Biaya medis } \\
\hline Obat-obatan & Bulan & 1.00 & 115000 & 1380000 \\
\hline Vitamin & Botol & 2 & 20700 & 552000 \\
\hline
\end{tabular}


Lanjutan Tabel 9.

\begin{tabular}{lcccc}
\hline Komponen biaya & Satuan & Jumlah Fisik & $\begin{array}{c}\text { Biaya per Satuan } \\
\text { (Rp) }\end{array}$ & $\begin{array}{c}\text { Jumlah biaya per } \\
\text { Tahun (Rp) }\end{array}$ \\
\hline $\begin{array}{l}\text { Transportasi } \\
\begin{array}{l}\text { Mobil dan motor } \\
\text { Gaji }\end{array}\end{array}$ & liter/bulan & 222.00 & 6500 & 17316000 \\
$\begin{array}{l}\text { Karyawan+THR } \\
\text { Total Biaya Variabel }\end{array}$ & Bulan & 4 & 1150000 & 59800000 \\
\hline
\end{tabular}

Pada kondisi pengembangan, biaya variabel telah disesuaikan dengan jumlah ternak. Tabel 9 di atas menunjukan rincian biaya variabel usaha ternak. Biaya variabel yang dibutuhkan untuk 40 ekor sapi perah, yaitu sebesar Rp 146133933 per tahun. Sementara itu, biaya tetap yang diperlukan dalam pengembangan usaha ditunjukan oleh Tabel 10 di bawah ini.

Tabel 10. Rincian biaya tetap kondisi pengembangan

\begin{tabular}{|c|c|c|c|c|}
\hline $\begin{array}{c}\text { Komponen } \\
\text { Biaya }\end{array}$ & Satuan & Jumlah & Biaya Per Unit (Rp) & $\begin{array}{c}\text { Total Biaya per } \\
\text { Tahun }\end{array}$ \\
\hline Listrik & bulan & 1 & 200000 & 2400000 \\
\hline Air & Bulan & 1 & 140000 & 1680000 \\
\hline Pajak PBB & Tahun & 1 & 50000 & 50000 \\
\hline Pajak mobil & unit/tahun & - & - & - \\
\hline Pajak motor & unit/tahun & - & - & - \\
\hline Pajak desa & Tahun & - & - & - \\
\hline Cicilan kavling & Bulan & - & - & 3276000 \\
\hline Gaji pemilik & Bulan & 1 & 2500000 & 32500000 \\
\hline \multicolumn{4}{|c|}{ Total Biaya Tetap } & 39906000 \\
\hline
\end{tabular}

Biaya tetap yang dibutuhkan sebesar Rp 39906000 per tahun. Pajak PBB pada kondisi pengembangan hanya memperhitungkan pajak bangunan kandang karena pajak tanah dan kandang sebelumnya telah diperhitungkan di kondisi lama. Total biaya operasional yang dibutuhkan per tahun adalah sebesar Rp 186039 933.

Pembiayaan usaha ternak kavling 176 dibagi menjadi pembiayaan oleh bank secara kredit dan pembiayaan dengan modal sendiri. Proporsi modal yang digunakan yaitu 70\% dibiayai kredit dan 30\% dibiayai modal sendiri. Tabel 11 menunjukan proporsi modal yang diperoleh usaha ternak kavling 176.

Tabel 11. Kebutuhan modal usaha kondisi pengembangan

\begin{tabular}{lcc}
\hline \multicolumn{1}{c}{ Komponen Biaya Usaha } & \% & Total Biaya \\
\hline Modal Investasi & & \\
Kredit & $70 \%$ & 490000000 \\
Dana sendiri & $30 \%$ & 210000000 \\
\hline Total Modal Investasi & & $\mathbf{7 0 0 0 0 0 0 0 0}$ \\
\hline Modal Kerja & & \\
Kredit & $70 \%$ & 10438163 \\
Dana sendiri & $30 \%$ & 4473498 \\
\hline Total Modal Kerja & & $\mathbf{1 4 9 1 1 6 6 1}$ \\
\hline
\end{tabular}


Total dana yang diperoleh dari kredit sebesar Rp 500438 163.00, sedangkan dana yang diperoleh dari modal sendiri sebesar Rp 214473 498.00. Pengembalian pembiayaan oleh kredit terdiri dari angsuran pokok dan bunga flat sebesar $11.60 \%$.

Susu yang dihasilkan oleh usaha ternak kavling 176 akan dijual ke koperasi terdekat. Harga yang ditawarkan diasumsikan naik 15\%. Tabel 12 menunjukan rincian pendapatan yang diperoleh usaha sapi perah.

Tabel 12. Penerimaan usaha ternak kondisi pengembangan

\begin{tabular}{lccccc}
\hline Uraian & Tahun 1 & Tahun 2 & Tahun 3 & Tahun 4 & Tahun 5 \\
\hline Total penjualan susu & 422280 & 469200 & 469200 & 469200 & 469200 \\
Sapi afkir \& dewasa (Rp) & 0 & 0 & 0 & 0 & 0 \\
\hline Total penerimaan & $\mathbf{3 6 7 2 0 0}$ & $\mathbf{4 0 8 0 0 0}$ & $\mathbf{4 6 9 2 0 0}$ & $\mathbf{4 6 9 2 0 0}$ & $\mathbf{4 6 9 2 0 0}$ \\
& & 000 & 000 & 000 \\
\hline
\end{tabular}

Pada kondisi pengembangan, tidak terdapat penjualan sapi afkir maupun sapi dewasa. Hal ini dikarenakan sapi yang dibeli merupakan sapi siap perah. Pada tahun pertama, sapi belum beroperasi secara penuh karena terdapat masa adaptasi dengan lingkungan baru. Setelah melewati masa adaptasi, sapi sudah dapat diperah secara normal dengan volume \pm 10 liter/ekor/hari. Volume total yang dihasilkan 40 ekor sapi dalam setahun yaitu 120000 liter.

III.5. Analisis Kriteria Investasi

Kriteria investasi digunakan untuk mengukur kemampuan suatu usaha. Kriteria investasi yang digunakan untuk menganalisis kelayakan usaha ternak kavling 176 adalah Net Present Value (NPV), Internal Rate of Return (IRR), Net B/C dan Payback Period. Tabel 13 menunjukan rincian analisi kriteria investasi pada usaha ternak sapi perah di kavling 176.

Tabel 13. Analisis kriteria investasi usaha

\begin{tabular}{lccc}
\hline Kriteria Investasi & Justifikasi Kelayakan & Nilai & Keterangan \\
\hline NPV (11.6\%) & $>0$ & Rp 292 514 822 & Layak \\
IRR & $>11.6 \%$ & $25.93 \%$ & Layak \\
Net B/C & $>1$ & 1.42 & Layak \\
PBP & $<5$ & 2.83 & Layak \\
BEP & & Rp 225 155564 & \\
\hline
\end{tabular}

1. NPV

Net Present Value didapat dari selisih PV manfaat dengan PV biaya. Pada usaha ternak kavling 176, nilai NPV bernilai positif. Hal ini menunjukkan bahwa selama 5 tahun manfaat bersih yang diterima oleh usaha ternak kavling 176 sebesar Rp 292514 822. Usaha dikatakan layak apabila nilai NPV yang diperoleh lebih besar dari nol.

2. IRR

Internal Rate of Return menggambarkan besar pengembalian yang didapat dari Investasi. IRR yang diperoleh pada usaha ternak kavling 176 lebih besar dari discount factor. Hal ini menunjukkan bahwa pengembalian yang diterima selama usaha berjalan yaitu sebesar $25.93 \%$. 


\section{Net B/C Ratio}

Net Benefit-Cost Ratio membandingkan manfaat bersih yang diterima dengan kerugian dari usaha. Net B/C Ratio yang diperoleh pada usaha ternak kavling 176 yaitu 1.42. Hal ini menunjukkan bahwa setiap Rp 1.00 yang dikorbankan akan menghasilkan manfaat bersih sebesar 1.42 . Net B/C Ratio akan layak bila nilainya lebih besar dari satu.

4. PBP

Payback Period digunakan untuk mengetahui waktu yang dibutuhkan agar investasi kembali. Payback Period yang digunakan tidak memperhatikan nilau waktu uang, sehingga waktu pengembalian investasi berdasarkan terkumpulnya nilai arus kas. Payback Period dikatakan layak bila kurang dari lamanya periode usaha. Nilai payback period yang diperoleh yaitu 2.83. Hal ini menunjukkan bahwa investasi akan kembali setelah 2 tahun 9 bulan 28 hari.

5. BEP

Break Event Point digunakan untuk mengetahui titik impas antara keuntungan dan kerugian. Titik impas rata-rata yang diperoleh pada usaha ternak kavling 176 yaitu Rp 225155 564. Artinya, usaha ternak kavling 176 akan berada dalam keadaan impas ketika usaha tersebut menghasilkan pendapatan sebesar Rp 225155564.

\section{III.6. Analisis Sensitivitas}

Analisis sensitivitas digunakan untuk mengetahui seberapa sensitif usaha terhadap perubahan yang mungkin terjadi. Peneliti melakukan analisis sensitivitas dengan tiga skenario yang berbeda. Skenario pertama, diasumsikan bahwa terjadi penurunan pendapatan yang diakibatkan pergantian musim. Pergantian musim menyebabkan sapi rentan tekena penyakit sehingga produksi susu menurun. Analisis sensitivitas skenario 1 ditunjukan oleh Tabel 14.

Tabel 14. Analisis sensitivitas skenario pertama

\begin{tabular}{lccc}
\hline \multicolumn{1}{c}{ Perubahan Variabel } & Basic & \multicolumn{2}{c}{ Skenario 1 } \\
\hline Penerimaan dari penjualan produk & 0 & turun 17\% & turun 18\% \\
Variabel Cost & 0 & Tetap & Tetap \\
Fixed Cost & 0 & Tetap & Tetap \\
Perubahan Kriteria Investasi & & & \\
NPV (Rp) & 292514822 & 9258568 & $(7403564)$ \\
IRR (\%) & $25.93 \%$ & $12.08 \%$ & $11.22 \%$ \\
Net B/C & 1.42 & 1.01 & 0.99 \\
PBP (tahun) & 2.83 & 4,02 & 4.13 \\
\hline
\end{tabular}

Usaha ini layak pada penurunan penerimaan sebesar $17 \%$. Pada penurunan sebesar $17 \%$ nilai NPV bernilai positif, IRR lebih besar dari $12.08 \%$ dan Net B/C lebih besar dari satu. Apabila penurunan terjadi sebesar $18 \%$, usaha ini menjadi tidak layak. Saat penurunan penerimaan sebesar 18\% nilai NPV menjadi negatif Rp 7403 564; Net B/C Ratio sebesar 0.99; dan IRR sebesar $11.22 \%$.

Skenario kedua menggambarkan kenaikan biaya variabel akibat penggunaan upah minimum regional (UMR) untuk daerah Kabupaten Bogor, yaitu sebesar Rp 2002 000. Hal tersebut mempengaruhi kenaikan biaya operasional, khususnya 
pada biaya variabel usaha. Tabel 15 menunjukan perubahan yang terjadi pada kriteria investasi akibat adanya perubahan biaya operasional akibat penggunaan UMR Kabupaten Bogor.

Tabel 15. Analisis sensitivitas skenario kedua

\begin{tabular}{lcc}
\hline \multicolumn{1}{c}{ Perubahan Variabel } & Basic & Skenario 2 \\
\hline Penerimaan dari penjualan produk & 0 & Tetap \\
Variabel Cost & 0 & Naik akibat penggunaan UMR \\
Fixed Cost & 0 & Tetap \\
Perubahan Kriteria Investasi & & 131213489 \\
NPV (Rp) & 292514822 & $18.17 \%$ \\
IRR (\%) & $25.93 \%$ & 1.19 \\
Net B/C & 1.42 & 3.40 \\
PBP (tahun) & 2.83 & \\
\hline
\end{tabular}

Kenaikan gaji karyawan dari Rp 1150000 pada kondisi pengembangan menjadi Rp 2002000 akibat penerapan UMR memberikan efek yang cukup besar pada usaha. Hal ini dapat terlihat dari penurunan yang terjadi pada criteria investasi dari keadaan basic. Kenaikan gaji karyawan akibat UMR menyebabkan nilai NPV menjadi Rp 131213 489, IRR menjadi 18.17\%, Net B/C Ratio menjadi 1.19 dan payback period sebesar 3.4 tahun.

Skenario ketiga merupakan gabungan dari skenario pertama dan kedua. Analisis sensitivitas skenario 3 ditunjukkan pada Tabel 16.

Tabel 16. Analisis sensitivitas skenario ketiga

\begin{tabular}{|c|c|c|c|}
\hline Perubahan Variabel & Basic & \multicolumn{2}{|c|}{ Skenario 3} \\
\hline Penerimaan dari penjualan produk & 0 & Turun 7\% & Turun $8 \%$ \\
\hline Variabel Cost & 0 & \multicolumn{2}{|c|}{ Naik akibat penggunaan UMR } \\
\hline Fixed Cost & 0 & Tetap & Tetap \\
\hline \multicolumn{4}{|l|}{ Perubahan Kriteria Investasi } \\
\hline NPV (Rp) & 292514822 & 14578561 & (2 083572$)$ \\
\hline IRR (\%) & $25.93 \%$ & $12.35 \%$ & $11.49 \%$ \\
\hline Net B/C & 1.42 & 1.02 & 1.00 \\
\hline PBP (tahun) & 2.83 & 3.99 & 4.09 \\
\hline
\end{tabular}

Kombinasi skenario 1 dan 2 pada penurunan pendapatan sebesar $7 \%$ dan kenaikan gaji karyawan akibat penggunaan UMR, ternyata masih dapat ditoleransi oleh usaha. Kombinasi yang menjadikan usaha ini tidak layak adalah ketika penurunan pendapatan sebesar 8\%. Pada keadaan tersebut nilai NPV menjadi negatif Rp 2083 572 IRR sebesar $11.49 \%$, dan Net B/C Ratio sebesar 1.00 dan payback period sebesar 4.09 tahun.

\section{III.7. Implikasi Manajerial}

Rekomendasi yang dapat digunakan pemilik usaha ternak untuk mengembangkan dan mengelola usahanya, antara lain : 
1. Peningkatan nilai tambah produk diperlukan untuk meningkatkan penghasilan. Pengembangan produk menjadi produk turunan seperti susu pasteurisasi, susu sterilisasi, dan yogurt.

2. Limbah kotoran sapi dapat dimanfaatkan selain untuk mengairi lahan tanam. Pemanfaatan dilakukan dengan menjadikan limbah sebagai biogas dan pupuk.

3. Usaha ternak sapi perah sangat berkaitan dengan perlakuan yang diberikan oleh tenaga kerja kepada sapi perah yang dirawat. Oleh karena itu, diperlukan penanaman budaya kerja seperti kejujuran, kedisplinan, dan kerja keras.

4. Pemilik usaha ternak perlu memiliki supplier tetap yang kualitas pakannya sudah dipastikan baik.

5. Usaha ternak kavling 176 yang tergolong cukup besar membutuhkan sistem pencatatan keuangan yang baik. Oleh karena itu diperlukan pencatatan harian mengenai pendapatan dan pengeluaran harian secara terperinci, sehingga cashflow bulanan dapat dihitung.

6. Intensitas pembersihan kandang sebaiknya tidak terbatas saat peternak memerah susu sapi. Pembersihan sebaiknya dilakukan sekitar 3-4 kali sehari untuk menjaga kebersihan ternak dan kandang.

7. Diperlukannya pengembangan teknologi pemerahan dengan menggunakan alat pemerah dalam usaha ini.

8. Manajemen yang terpisah dibutuhkan dalam usaha ini. Usaha yang semakin berkembang akan menjadi lebih komplek, sehingga mulai dibutuhkan pemisahan antara bagian keuangan, produksi dan SDM.

\section{Kesimpulan}

Berdasarkan hasil penelitian yang telah dilakukan pada usaha ternak kavling 176, dapat disimpulkan bahwa usaha ini dikatakan layak dikembangkan dari segi aspek non finansial. Usaha ternak kavling 176 juga layak dari segi aspek finansial. Hal ini terlihat dari kriteria investasi usaha yaitu NPV sebesar Rp 292514 822, IRR sebesar 25.93\%, Net B/C Ratio sebesar 1.42, PBP selama 2 tahun 9 bulan 28 hari, dan BEP sebesar Rp 225155564.

Hasil analisis sensitivitas pada skenario pertama menunjukan bahwa usaha ternak kavling 176 tetap layak pada penurunan pendapatan hingga 17\% dengan perubahan kriteria investasi yaitu: nilai NPV turun menjadi Rp 9258 568, IRR turun menjadi $12.08 \%$, Net B/C turun menjadi 1.01 dan PBP bertambah menjadi 4.02 tahun. Hasil analisis sensitivitas pada skenario kedua menunjukan bahwa kenaikan biaya operasional akibat penggunaan upah minimum regional (UMR) Kabupaten Bogor sebesar Rp 2002000 tetap menjadikan usaha ini layak dengan perubahan kriteria investasi yaitu: nilai NPV sebesar Rp 292514 822, IRR sebesar 18.17\%, Net B/C turun menjadi 1.19 dan PBP meningkat menjadi 3.40 tahun. Sementara itu, pada skenario ketiga yang merupakan kombinasi dari penurunan pendapatan dan kenaikan biaya operasional akibat penggunaan UMR menjadikan usaha ini tetap layak pada kombinasi 7\% dengan perubahan kriteria investasi yaitu: nilai NPV turun menjadi Rp 14578 561, IRR turun menjadi $12.35 \%$, Net B/C turun menjadi 1.02 dan PBP bertambah menjadi 3.99 tahun. 
138 |Poetri, Basith, Wijaya - Analisis Kelayakan Pengembangan Usaha

\section{Daftar Pustaka}

Adi S, Ina R, Budi S. 2005. Beternak Sapi Perah Secara Intensif. Jakarta (ID): Agromedia Pustaka.

[Ditjen PKH] Direktorat Jenderal Peternakan dan Kesehatan Hewan. 2012. Produksi susu provinsi. [Internet]. [diunduh 2013 April 30]. Tersedia pada: http://www.deptan.go.id/infoeksekutif/nak/isi dt5thn nak.php

Nurtini S. 2011. Pidato Pengukuhan Jabatan Guru Besar: Insentif Ekonomi Peternak Sapi Rakyat [komunikasi singkat]. Hal: 4-6.

Nurmalina R, Tintin S, Arif K. 2009. Studi Kelayakan Bisnis. Bogor (ID): Departemen Agribisnis Fakultas Ekonomi dan Manajemen Institut Pertanian Bogor.

Siregar S, Kusnadi U. 2004. Peluang Pengembangan Usaha Sapi Perah di Daerah Dataran Rendah Kabupaten Cirebon. Jurnal Media Peternakan. 27(2): 77-87.

Willyanto, Alia A, Dwi A, Lily T. 2011. Ensiklopedia Jawa Barat edisi 3. Jakarta (ID): PT Lentera Abadi.

Yusdja Y. 2005. Kebijakan Ekonomi Industri Agribisnis Sapi Perah di Indonesia. Jurnal Analisis Kebijakan Pertanian. 3(3): 257-268. 